DOI: $10.30842 /$ ielcp230690152452

Grigory Vorobyev

(Institute for Linguistic Studies, RAS, St. Petersburg)

\title{
THEODORE GAZA'S NEOLOGISMS IN -CILLA/-CULA AND THE ROLE OF SIXTEENTH-CENTURY REFERENCE BOOKS IN THE FORMATION OF ORNITHOLOGICAL NOMENCLATURE ${ }^{1}$
}

This article continues a series of papers on Latin bird names coined by Theodore Gaza in his translation of Aristotle's Historia animalium.

Varro explains the etymology of the bird name motacilla as follows: "quod semper movet caudam" ( $L L 5,76)$. Following this explanation, Theodore Gaza, the author of the Latin translation of Aristotle's Historia animalium printed in 1476 and extremely authoritative in the sixteenth century, inferred the existence of the word cilla 'bird tail, rump'. Perhaps he drew this idea from a medieval glossary. In any case, it was only for rendering Greek bird names with the component 'rump' or 'tail' that he

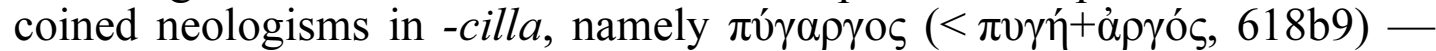

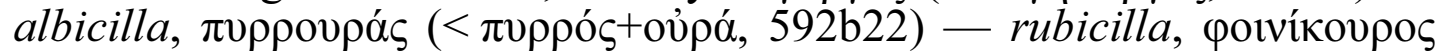

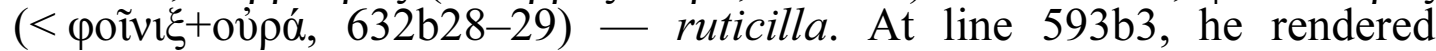

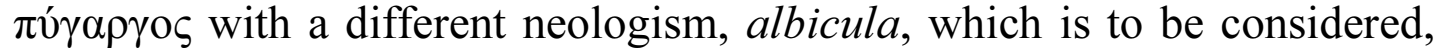
given the clear etymology of the Greek word, a compound formed from cūlus 'the posteriors, fundament' rather than a diminutive. Therefore, the word rubecula that Gaza coined translating the bird name Éí $\theta \alpha \kappa o \varsigma$ should be, apparently, interpreted as a similar formation, from غ̇ $\rho \theta \rho \rho o ́ \varsigma$ 'red' and $\theta \tilde{\alpha} \kappa o \varsigma$ 'seat'.

The proposed etymology of these bird names sheds light upon Gaza's method of treating variant readings in the Greek text. It turns out that, at least twice, he translated two variae lectiones of the same word and put both in his Latin text, one after another. Certainly, this could be explained by the presence of an incorporated gloss in one of Gaza's Greek Vorlagen, not attested in manuscripts extant today, but it could also indicate a contaminative tendency in Gaza's way of translating.

In the second part of the article, early modern reception of the aforementioned Greek and Latin bird names is traced. Namely, it is shown how William Turner's 1544 Avium praecipuarum, quarum apud Plinium et Aristotelem mentio est, brevis et succincta historia influenced the formation of modern ornithological nomenclature. The studied cases show that Turner's identifications of Aristotle's bird names with contemporary vernacular ones defined the fate of the Greek words and their Neo-Latin equivalents. Together with the 1555 ornithological volume of Conrad Gessner's Historia animalium where those identifications were taken over,

\footnotetext{
${ }^{1}$ The study was supported by the RFBR, research project РФФИ № 20012-00357.
} 
Turner's book launched the process of reassigning meanings, a process crucial for the establishment of modern animal nomenclature.

Keywords: Latin bird names, Greek bird names, neologisms, compounds, diminutives, zoological nomenclature, sixteenth-century reference books, Aristotle, Theodore Gaza, William Turner, Conrad Gessner, Pierre Belon.

Г. М. Воробьев

(Институт лингвистических исследований РАН, Санкт-Петербург)

\section{Неологизмы Феодора Газы на -cilla/-cula и роль справочников XVI века в становлении научной номенклатуры птиц}

Варрон объясняет внутреннюю форму названия птицы motacilla: «quod semper movet caudam» (Varro LL 5, 76; «поскольку все время шевелит хвостом»). Следуя этому утверждению, Феодор Газа, автор латинского перевода «Истории животных» Аристотеля, напечатанного в 1476 г. и исключительно популярного в XVI в., сделал вывод, будто существует слово cilla 'птичий хвост, гузка'. Он мог позаимствовать это представление из какого-то глоссария. Очевидно, именно поэтому при переводе греческих названий птиц с компонентом 'хвост' или 'гузка', и только для таких слов, он

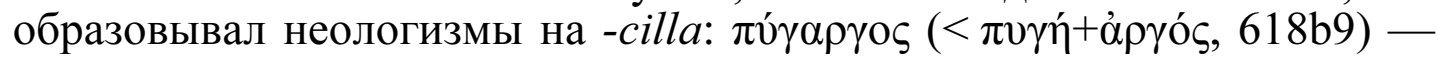

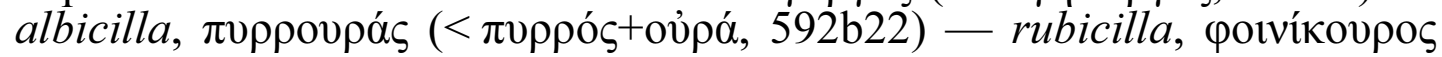

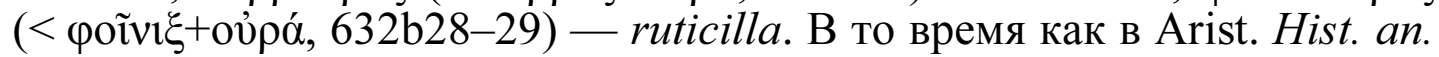

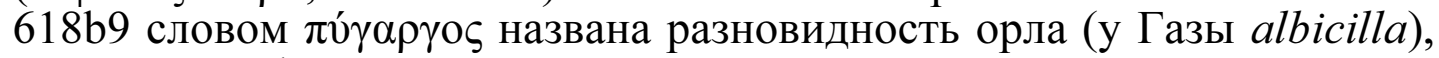
в строке 593b3 это же слово, засвидетельствованное только в части рукописей и не принятое большинством издателей, встречается в перечислении птиц, кормящихся у пресных водоемов. Поэтому здесь Газа переводит его иначе: не albicilla, a albicula. Учитывая

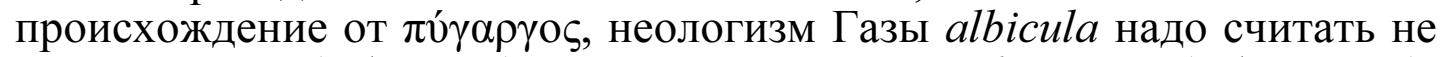
диминутивом ( белянка), а производным от cūlus 'зад' ( белогузка), образованным, вероятно, по модели obstipecūlus, hirsuticūlus или sesquecūlus. Существование неологизма Газы albicula заставляет предположить, что и в неологизме rubecula, использовавшемся Газой

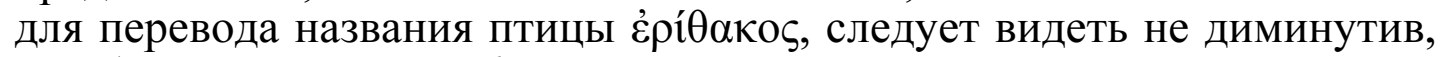
а образование от cūlus, то есть он, вероятно, восстанавливал

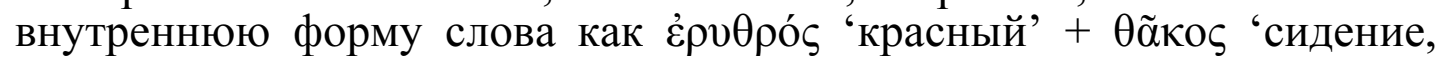
седалище'.

Регулярность использования композитов, образованных по модели «цветообозначение + -cilla/-cūla» позволяет сделать вывод, что «rubecula, silvia» у Газы в Arist. Hist. an. 592 b22 отражает не

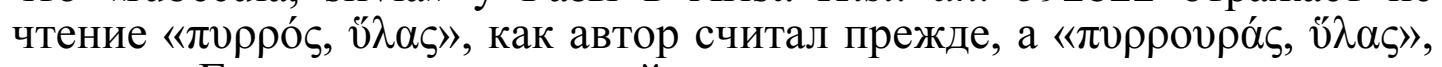
то есть Газа включил в свой текст взаимоисключающие чтения, проиосходящие из разных ветвей рукописной традиции. То же самое происходит в строке 593b3, где он помещает один за другим переводы

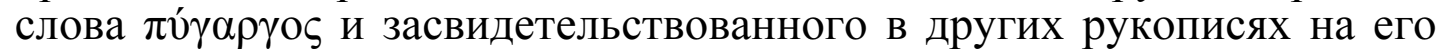
месте «о $\tau \rho v ́ \gamma \gamma \alpha \varsigma »: ~ « a l b i c u ̄ l a$, tringa». Возможно, это связано с тем, что в одной из греческих рукописей, которые Газа использовал, глосса, содержавшая альтернативный вариант, была инкорпорирована в 
текст; не исключено, однако, что он целенаправленно совмещал в своем переводе разные чтения одного и того же слова.

Во второй части статьи на примере этих неологизмов Газы показано, как «Краткая история птиц, упомянутых у Плиния и Аристотеля» Вильяма Тернера (1544г.), первый орнитологический справочник Нового времени, повлияла на формирование латинской номенклатуры птиц. Тернер впервые попытался систематически отождествить с современными английскими и немецкими названиями птиц названия, упомянутые в «Истории животных» Аристотеля. Последнего он цитировал в переводе Газы и рассматривал греческие названия птиц вместе с их эквивалентами из перевода. Отождествления Тернера были переняты в орнитологическом томе чрезвычайно авторитетной «Истории животных» Конрада Гесснера (1555 г.). Поэтому, судя по рассмотренным примерам, греческие названия в латинской транслитерации и латинские эквиваленты, введенные Газой, закреплялись в научной номенклатуре именно в тех значениях, которые предложил Тернер. Перераспределение значений происходило уже в XVIII в., в связи с введением новых таксонов.

Ключевые слова: латинские названия птиц, греческие названия птиц, неологизмы, композиты, диминутивы, зоологическая номенклатура, справочники XVI века, Аристотель, Феодор Газа, Вильям Тернер, Конрад Гесснер, Пьер Белон

\section{Theodore Gaza's neologisms in -cilla and -cula 1.1. Albicilla and ruticilla}

The Latin bird name motacilla is attested once in Pliny (HN 37, 156, 2), en passant ${ }^{2}$, and once in Varro, who explains it as follows: "motacilla quod semper movet caudam" (Varro LL 5, 76). This explanation, based on the interpretation of the first part of the word as the root mot- 'to move', should have been based on a folk etymology. Indeed, Ernout and Meillet (Ernout, Meillet, 2001: 416) suggest comparing motacilla with $\mu v^{\tau} \tau \tau \xi$, registered by Hesychius

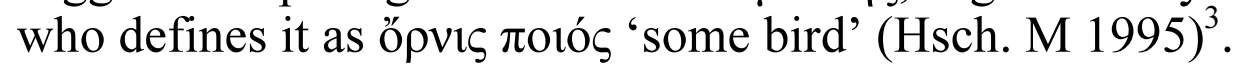

2 "Chloritis herbacei coloris est; eam in ventre motacillae avis inveniri dicunt magi congenitam ei" ("Chloritis is a stone of a grass-green colour: according to the magicians, it is found in the crop of the motacilla, being engendered with the bird", cited according to: Pliny 1897: 452; transl. from Pliny 1857: 446). - In quotations, I set animal names in italics. Early modern sources are cited from their first editions. Punctuation and orthography, including capitalization, is normalizaed in the quotations. The correspondences between modern vernacular bird names and the scientific nomenclature are based on Boehme, Flint 1994 and HBW.

${ }^{3}$ Max Niedermann supported Varro's etymology and considered the bird name a composition of motare 'to move about, move intensely' and cūlus 'the posteriors, fundament', originally *motacūla or *motacŭlla, that later on was modified, analogically to diminutives in -illa, to become motacilla 
Still, Varro's etymology is responsible for the interpretation of the second part of the word motacilla as a root meaning 'tail' or 'rump'. Thus the phantom word cilla, or rather the phantom root cill-, originated. Cilla is not attested per se, but it was used to form several compounds in the fifteenth century.

Numerous neologisms ${ }^{4}$ designating animal species were coined by the Byzantine scholar Theodore Gaza in his Latin translation of Aristotle's Historia animalium, made in Italy between 1454 and 1473/1474. It was first printed in 1476 and enjoyed great success in the sixteenth century (cf. Monfasani 1999; Beullens, Gotthelf 2007). Many of the words introduced by Gaza made their way into the times after Carl von Linné ${ }^{5}$. Varro's etymology of motacilla,

(Niedermann 1897: 65). Niedermann compares it with the parallel structure

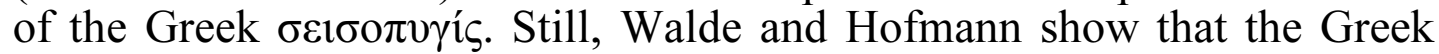

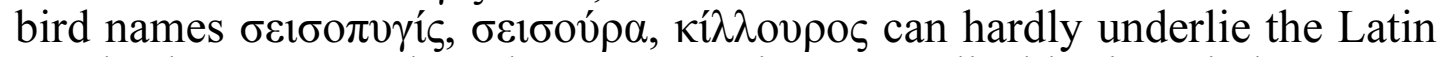
word; they argue that the $-a$ - remains unexplicable in Niedermann's etymology, for one would rather have expected *moticilla. They also convincingly refute the etymology from muto 'penis' and cillĕre 'to move', the existence of the latter being rather questionable, for it is attested only in ancient grammatical texts and glosses for explaining the etymology of oscillare and diminutives like furcilla (Ernout, Meillet 2001: 120-121), cf. TLL s.v. cillo, where the entry is marked with "si vera vox est"; the Greek $\kappa i \lambda \lambda<0>v \rho o \zeta$ (attested only in Hsch., as a synonym of $\sigma \varepsilon 1 \sigma o \pi v \gamma i \varsigma$ ), was suggested to be connected with a Baltic word for wagtail (Lithuanian kielé, Latvian ciēlava, Old Prussian kylo) that could have been derived from a

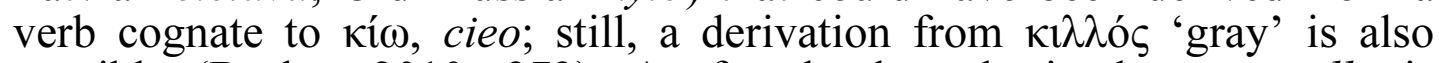
possible (Beekes 2010: 373). As for the hypothesis that motacilla is connected with $\mu \nu$ $\tau \tau \eta \xi$, supported by Ernout and Meillet, Walde and Hofmann do not approve of it, without any argumentation: "Die Versuche, -āc-als ursprünglich zu fassen, führen kaum zum Ziel" (Walde, Hofmann 1938-1954, vol. 2: 115). Michiel de Vaan's dictionary does not mention the word motacilla (De Vaan 2008). - On Varro's etymology of motacilla cf. Jobling 2010: 261, Jobling 2020, s.v. Motacilla: "The mistaken use of cilla for 'tail' in ornithology goes back to mediaeval writers who misread motacilla, Varro's name for the wagtail ("quod semper movet caudam") and a diminutive from motare 'to move about' or 'shake' (i.e. 'a little shaker or wagger'), as 'shaketail'".

${ }_{5}^{4}$ On early modern Latin neologisms, see Helander 2014.

${ }^{5}$ The role of the translations of Aristotle in the formation of modern nomenclature of fishes is studied in Beullens 2008. Opening thus a new research path, Beullens confined himself to the names of fishes and had to admit that almost no fish names introduced by medieval and humanist translators of Aristotle's Historia animalium entered modern binary nomenclature. Still, applying Beullens' approach to other parts of the animal nomenclature, e.g. to the names of birds, and checking all the occurrences systematically, it can be discovered that post-Linnaean 
perhaps mediated by a glossary that already included cilla as a lexeme, made Gaza consider the second part of the bird name motacilla as a root meaning 'tail' or 'rump'. Indeed, he rendered Aristotle's $\pi$ v́ $\alpha \rho \gamma o \varsigma$, name of an eagle (with clear etymology as a composition of $\pi v \gamma \eta$ ' 'rump, buttocks' and à $\rho \gamma o ́ \varsigma$ 'shining, white', cf.

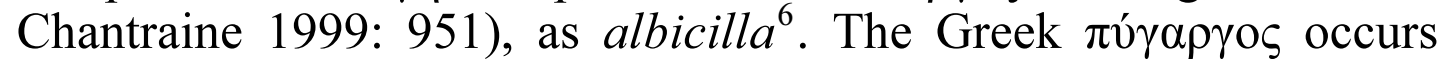
twice, Arist. Hist. an. $563 \mathrm{~b} 6$ and $618 \mathrm{~b} 19$. Besides, at 593b5, it is attested as a variant reading where the commonly accepted lemma is

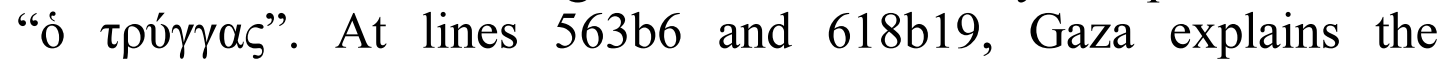
etymology of $\pi$ v́ $\alpha \rho \gamma o \varsigma$, attested in transliterated form pygargus in Pliny: "Aquilarum plura sunt genera. Unum quod pigargus ab albicante cauda dicitur, ac si albicillam nomines..." (618b19; Aristotle 1476: f. n [9]r; ms. Vat. lat. 2094, f. f. 143v, 1. 3 from below) and "Genera aquilarum non aeque omnia prolem fastidiunt, sed difficilior in alendo una cui nomen pygargo cauda albicans dederat" (563b6, with attractio casus; here without the Latin variant albicilla; Aristotle 1476: f. i 3r; ms. Vat. lat. 2094, f. 87r, 1.3 from below). On the occurrence at line 593b5, see section 1.3.

A similar case is Gaza's neologism ruticilla, a rendering of the Greek poivíkovpos, apparently a compound of rutilus 'red, reddish' and the phantom -cilla. The Greek word occurs twice in the Hist. $a n$., at lines $632 \mathrm{~b} 28$ and $632 \mathrm{~b} 29$ (the passage will be analyzed in the section 1.3$)^{7}$.

nomenclature in fact owes much to the translators of Aristotle (cf. Vorobyev 2015).

${ }^{6}$ The Swiss polyhistor Conrad Gessner implicitly approved of the interpretation of cilla as 'bird tail, rump'. Namely, when he recalled a Modern Greek bird name that he cited as asprocolos, he adduced a classicizing variant, leucopygos ( $<\lambda \varepsilon v \kappa o ́ \varsigma$ 'white' $+\pi v \gamma \eta$ 'rump, buttocks') and, as a Latin translation, albicilla (Gessner 1555: 370). - The word cilla was still considered existing by Jacob Grimm. Discussing word composition in his German Grammar, he noted: "Nähere Forschung lässt im Latein einzelne Zusammensetzungen wahrnehmen, die den griechischen gleichen. Varro 4, 11. Plinius 37, 10. gebrauchen motacilla (motans, agitans caudam, von einem veralteten Substantiv cilla, cauda, das $\mathrm{zu}$ cillere gehört), ist es dem griechischen $\sigma \varepsilon 1 \sigma$-oú $\rho \alpha$ nachgebildet? Das deutsche wipp-sterz, italienische squassa-coda entspricht gerade so" (Grimm 1826: 980-981). On the verb cillere cited by Grimm, see n. 3 above.

${ }^{7}$ Besides, it appears in Hesychius ( $\Phi$ 707) and in the Geoponica (15, 1, 22, 3 ), both instances based on the cited passage from the Hist. an. Transliterated as phoenicurus, it is mentioned in Pliny $(H N 10,86,3)$, also based on Aristotle's passage. Its etymology appears transparent, 'red-tail' (neither Frisk, nor Chantraine, nor Beekes mention this word). - In his 
Apart from albicilla and ruticilla, Gaza's translation contains a similar bird name, rubicilla, which deserves special attention.

\section{2. Rubicilla. A contaminated reading of Arist. Hist. an. $592 \mathrm{~b} 22$}

At line 592b22, in a list of grub-eating birds, the last edition of Aristotle's Historia animalium, prepared by David M. Balme and

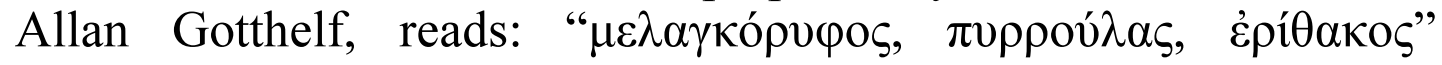
(Aristotle 2002: 342). The word $\pi v \rho \rho o v ́ \lambda \alpha \varsigma$ is a hapax legomenon, which is, in this form, attested in no extant manuscript. For this word, Balme's edition lists the following variants: $\pi v \rho \rho o v \lambda \alpha \varsigma^{\prime} L^{c} r c$.

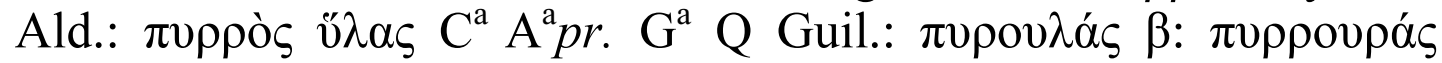
$\mathrm{A}^{\mathrm{a}} r c$. Fa $\mathrm{X}^{\mathrm{c}} \gamma$ (exc. $\mathrm{L}^{\mathrm{c}} r c$.). The shift of the accent, from $\pi v \rho \rho o v \lambda \alpha{ }^{\prime} s$ to $\pi v \rho \rho o v ́ \lambda \alpha \varsigma$, is due to Aldus Manutius' intervention in Aristotle 1497 (on this word, see Vorobyev 2018: 249; Vorobyev 2019: 179$185)^{8}$.

Theodore Gaza's rendering of the passage " $\mu \varepsilon \lambda \alpha \gamma \kappa o ́ \rho v \varphi о \varsigma$,

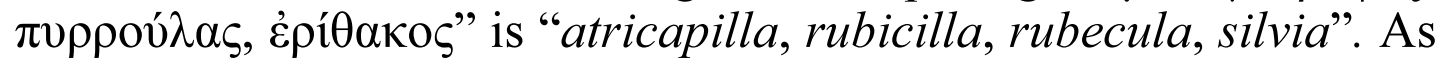
shown in Vorobyev 2018, atricapilla stands for $\mu \varepsilon \lambda \alpha \gamma \kappa o ́ \rho v \varphi о s$,

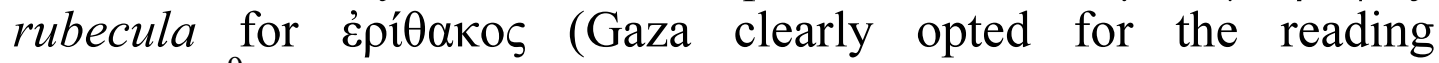

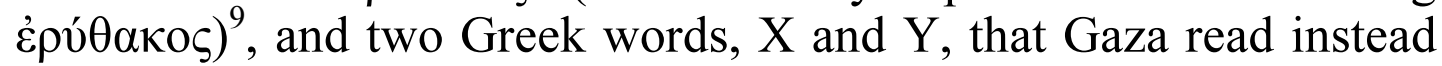
of $\pi v \rho \rho o v ́ \lambda \alpha \varsigma$ were rendered as rubicilla and silvia. Thus, we might

new translation of the Historia animalium, made in the 1530s and published posthumously in 1619, Julius Caesar Scaliger, who constantly criticized Gaza's version, suggested punicilla instead of ruticilla (Aristotle 1619: 1169). Thus, he followed the same derivation pattern, using punicus as an etymologically more precise equivalent of $\varphi \circ \tilde{i} v \xi \xi$ than rutilus. Scaliger's translation was printed too late to eclipse the authority of Gaza's text, so Scaliger's neologisms did not enter the scientific nomenclature.

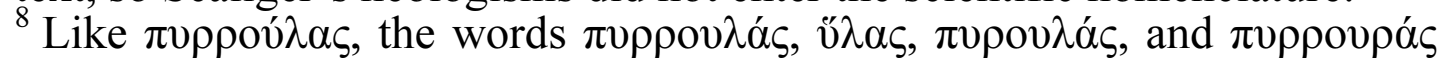
are hapax legomena. - For the explanation of the sigla, see Aristotle 2002: 50-52; on the manuscript tradition of the Hist. an., see Berger 2005. Now that the first critical edition of the Arabic translation of the Hist. an., by Lourus S. Filius, has been published, it is possible to take the Arabic tradition into consideration. Even though Filius' edition reads here one word, brūsūlās (Aristotle 2018: 280), it has an $s$ in the middle (as it is also clear from Michael Scot's transliteration, forozcheloz, Aristotle 1994), which apparently indicated that the Greek text underlying the Arabic

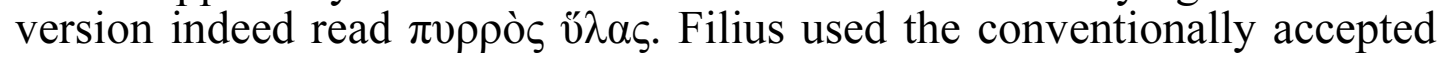

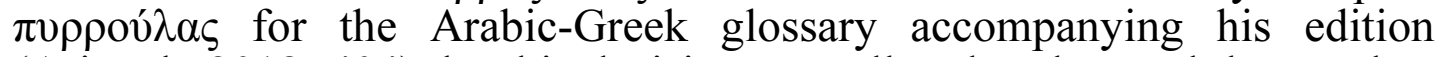
(Aristotle 2018: 404), but his decision to spell and understand the word as one had been most probably based on the tradition of the Greek text accepted since Aldus.

${ }_{9}^{9}$ The latter reading, clearly referring to $\dot{\varepsilon} \rho v \theta \rho$ ó $\varsigma$ 'red', is present in all manuscripts of the family $\alpha$, except $C^{\mathrm{a}}$ (Aristotle 2002: 342 ). 
reconstrut the Greek text that he was translating like this:

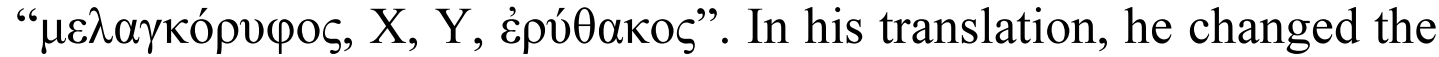
word order, striving for rhetorical euphony ("atricapilla, rubicilla, rubecula, silvia"), whereas the correct order would have been "atricapilla, rubicilla, silvia, rubecula").

In Vorobyev 2018 and 2019, I argued that Gaza's X was $\pi v \rho \rho o ́ s$

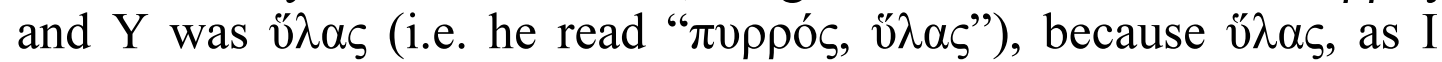
then demonstrated, was what he rendered as silvia. I thought that Gaza's rubicilla stood for $\pi v \rho \rho o ́ s$, considering -cilla just a diminutive suffix (Vorobyev 2018: 253, n. 27). However, I have to admit that I then misinterpreted rubicilla and ruticilla as diminutives and did not take into consideration the word albicilla at all ${ }^{10}$. Now, the analysis of albicilla and ruticilla (from $\pi \dot{v} \gamma \alpha \rho \gamma o s$ and

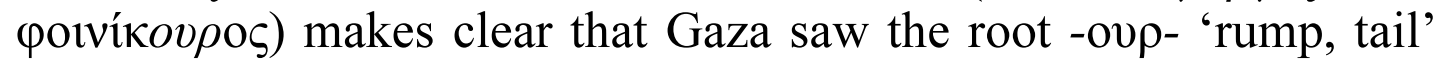
in the word X he was translating at line 592b22. Therefore, choosing out of the variants attested in the manuscript tradition, it must be accepted that $\mathrm{X}$ should have been $\pi v \rho \rho o v \rho \alpha ́ \zeta$, i.e. Gaza must have reconstructed the Greek text as " $\mu \varepsilon \lambda \alpha \gamma \kappa o ́ \rho v \varphi о \varsigma, \pi v \rho \rho o v \rho \alpha ́ \varsigma, ~ v " \lambda \alpha \varsigma$,

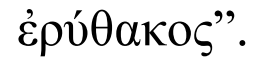

This contaminated reading, barbarian from the point of view of modern philology, was supposedly, rather than due to a gloss incorporated into the text by a scribe in one of Gaza's Greek Vorlagen, Gaza's own intervention. Indeed, his propensity to manipulating the text is known (Perfetti 1995: 261-283), as is also known that he used several Greek manuscripts of Aristotle's text (Dittmeyer 1902: 31-35; Berger 2005: 144, 155). Hence he must have realized that $v \lambda \alpha \varsigma$ was but a part of the reading $\pi v \rho o v \lambda \alpha \alpha_{\zeta}$, for

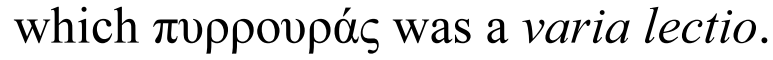

\section{3. Albicula and rubecula}

Similar contamination occurs at line 593b5 where, in a list of birds feeding by lakes and rivers, part of the codices (families $\beta$ and

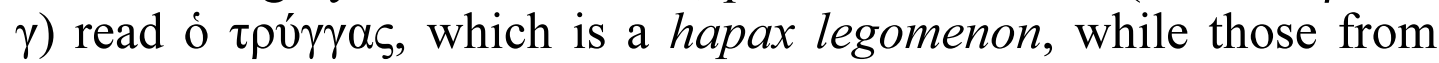

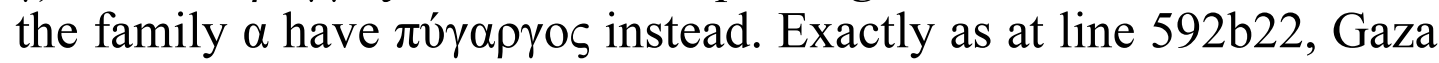

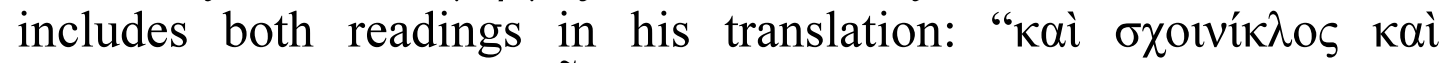

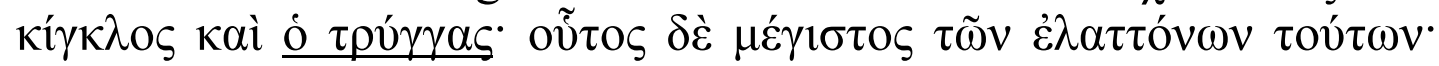

\footnotetext{
${ }^{10}$ In Vorobyev 2015, it was missed out by oversight, as well as albicula that will be discussed below; only the transliterations pigargus and pygargus were registered then. - On the double diminutives in -cillus, cillum (formed from diminutives in -culus, -culum), see e.g. Glare 2012: 344, s.v. -cillum and -cillus: corcillum, oscillum, caesticillus, penicillus.
} 


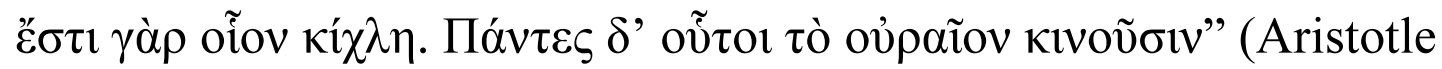
2002: 345); "ad haec iunco, cinclus, albicula, tringa, quae inter minora haec maiuscula est, turdo enim aequiparat. Omnibus his cauda motitat" (Aristotle 1476: f. 1 [9]r-v; ms. Vat. lat. 2094: f. 118r, 11. 3-4).

Apart from providing a perfect comparandum for the case of contamination at line 592b22, line 593b5 offers a new word, albicula, not attested elsewhere in Gaza's translation. As mentioned

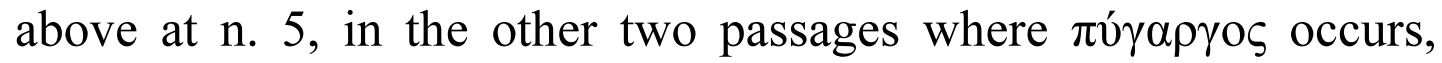
$563 \mathrm{~b} 6$ and $618 \mathrm{~b} 19$, Gaza renders it as pygargus/pigargus and, at $618 \mathrm{~b} 19$, adds his Latin variant, albicilla. It seems that at line 593b5 $\pi v ́ \gamma \alpha \rho \gamma o \varsigma$ is rendered as albicula on purpose, for Gaza might have

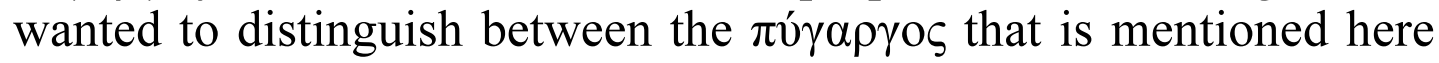
among small birds with frequently moving tail (one of the wagtails?) and the other $\pi$ v́ $\gamma \alpha \rho \gamma o \varsigma$ which is explicitly described as a kind of eagle at $563 \mathrm{~b} 6$ and $618 \mathrm{~b} 19$. The fact that albicula is a rendering of $\pi$ v́ $\alpha \rho \gamma o \varsigma$ makes clear that, apart from -cill-, Gaza considered -culas another root meaning 'rump, bird's tail', apparently from cūlus 'the posteriors, fundament' (therefore, we should pronounce albicūla, not albicŭla).

Now, the word albicula helps interpreting the origin of the above mentioned rubecula, a better known neologism of Gaza's coinage, present in today's scientific name of the robin-redbreast, Erithacus rubecula (Linnaeus, 1758) ${ }^{11}$.

The Greek bird name Épí⿴囗⿱一一) Hist. an. (592b22, extensively discussed above, 632b28, and 632b29), as well as in other ancient sources. Sundevall considers it a

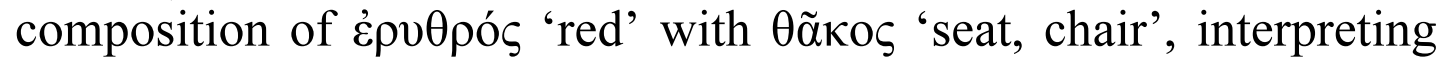
the latter as 'rump, buttocks' (Sundevall 1863: 110-111), thus implying that the denotatum should be a bird with reddish tail- or rump-feathers (as in the vernacular names of the common redstart: English redstart, German Rotsteiss or Rotschwanz, Italian codirosso, Russian горихвостка, etc.). Indeed, he suggests identification with the common redstart in its summer feathering.

D'Arcy W. Thompson criticizes Sundevall's etymology as farfetched, thus refuting the requirement for the species denoted by the Greek word to have a reddish rump or tail ${ }^{12}$. Furthermore,

${ }^{11}$ Here and in the following, the references to the sources of taxa are provided in round brackets, with a comma before the year, whereas conventional bibliographical references are typed without the comma.

${ }^{12}$ A strong argument against Sundevall's etymology is the existence of the

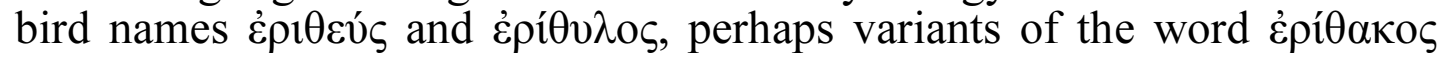


Thompson argues for the identification of źi $\theta \alpha \kappa \circ \varsigma$ with the robinredbreast, for the latter corresponds better to Aristotle's description of the time of the year when the bird called spítakos can be seen (Thompson 1895: 57). Indeed, no etymological dictionary of Ancient Greek mentions Sundevall's derivation. Thus, Hjalmar

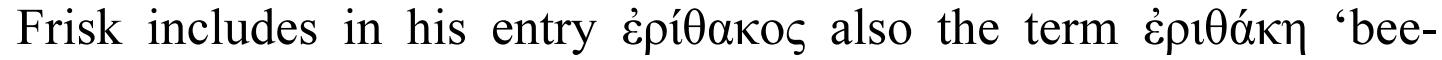
bread' and considers both words, even though with reserve, derived

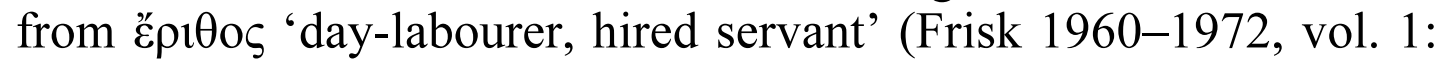

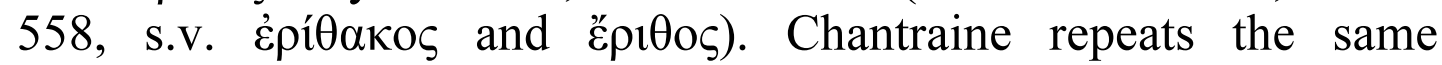
hypothesis in his dictionary but wonders what reasons might have

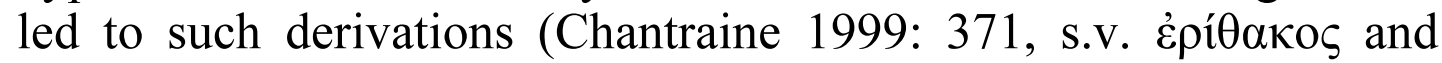

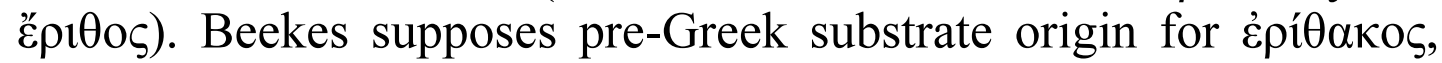
with a question mark though (Beekes 2010: 458).

In any case, Gaza translates Épí $\theta \alpha \kappa o \varsigma$ with the Latin rubecula, apparently of his coinage ${ }^{13}$. Two interpretations of this word are possible. The first explains it as a diminutive, following the pattern of vulpis $>$ vulpecula, or else niger $>$ nigriculus or pinguis $>$ pinguiculus $^{14}$. The second interpretation, from rubeus 'red' and cùlus 'the posteriors, fundament', is analogical to the aforementioned albicula, for which this derivation is corroborated by the existence of the variant albicilla, as well as ruticilla (see above). If the latter explanation of Gaza's neologism rubecula is correct, it means that he understood the etymology of غंpí $\theta \alpha \kappa$ exactly as Sundevall did some four centuries later (and both were wrong, according to modern etymologists, see above). Indeed, even though rare, parallel compounds are attested, namely sesquecūlus,

(Thompson 1895: 57). W. Geoffrey Arnott, in his 2007 encyclopedia Birds in the Ancient World from $A$ to $Z$, conceived as an updated version of Thompson's Glossary of Greek Birds, does not discuss the etymology of these words (Arnott 2007: 72-73). - Albert-Gaston Camus, who edited the Hist. an. in 1783 with a French translation and a commentary, suggested derivation from épis 'quarrel' alluding at the bird's propensity to 'quarrelling': "On pretend même que le nom grec lui (sc. au rouge-gorge) convient très bien, parce qu'il est fort querelleur", and in the footnote: "Le

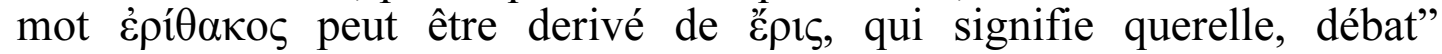
(Aristotle 1783, vol. 2: 734). This suggestion, as far as I know, was not discussed by later authors, but it appears hardly plausible, for the second part of the word remains without explanation.

${ }^{13}$ Yet, it is not excluded that Gaza could have encountered it in a certain manuscript glossary, since similar words, rubiculus/rubicula, are attested in medieval sources (Du Cange 1887: s.v.).

${ }_{14}$ Theoretically, a better variant would have been probably rubeus $>$ rubeola, like aureus > aureola, or ruber > rubella, like pulcher > pulchella, cf. Leumann 1977: 306-307. 
obstipecūlus, and hirsuticūlus ${ }^{15}$. Gaza may have used one of those as the model for his derivation.

An argument against the interpretation of Gaza's rubecula as 'red-rump' might be provided by the following passage, the only one where the غpí⿴囗⿱一一)

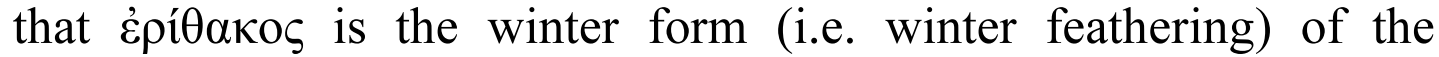
pouvíkovpos. Gaza's translation has an addition that, apparently, has never been taken into consideration:

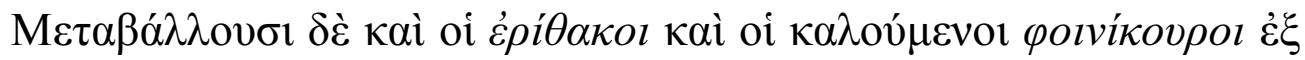

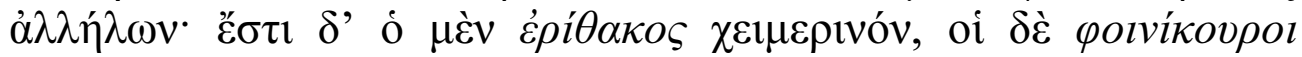

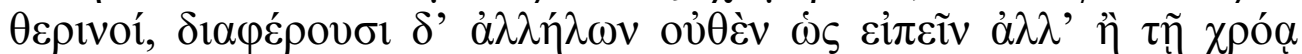
uóvov (Aristotle 2002: 469).

Rubeculae et quae ruticillae appellantur invicem transeunt. Estque rubecula hiberni temporis, ruticilla aestivi. Nec alio fere inter se differunt, nisi pectoris colore et caudae (Aristotle 1476: f. o [9] v[10]r; Vat. lat. 2094: f. 158v, 11. 3-6).

The addition of "pectoris et caudae" is, surely, one of the interpolations characteristic of Gaza's translation. Now, one might argue that, by this interpolation, Gaza meant that Aristotle's porvíkoupos had reddish tail (which was evident from the form of the word) while غ́pi $\theta \alpha \kappa o s$ had reddish breast. Still, another

${ }^{15}$ As for sesqueculus, it is attested, as a further cognomen of Gaius Iulius Caesar Strabo Vopiscus, in Marius Victorinus' Ars grammatica 4, 3 (a thorough analysis of this word, with its variant sesquiculus, is provided in Dahlmann 1973: 19-22). Hirsuticulus is a translation of $\delta \alpha \sigma 0 ́ \pi \rho \omega \kappa \tau o \varsigma$ and is transmitted in manuscripts as hirsiculus, hirsuticulus being an emendation; other emendations that have been proposed are hirticulus and hystriculus, a diminutive of hystrix 'porcupine'. For obstipeculus, a variant reading obstipecollus is attested (for hirsuticulus and obstipeculus, attested only in glossaries, see Bader 1962: 149). In any case, if Gaza was acquainted with at least one of these words in -culus, it should have been enough for him to deem their derivation pattern productive. - The explanation of rubecula, proposed by James A. Jobling, as a modification of rubecola that, in turn, is based on rubus 'bramblebush' and -cola 'dweller', is apparently not supported by any medieval or early modern text. Furthermore, Jobling does not refer to Gaza or any other source, just noting that it is a Medieval Latin word (Jobling 2010: 339). The spelling rubecola that, indeed, appears in some eighteenth- and nineteenth-century sources must be, on the contrary, a late distortion of rubecula (like, on the contrary, Gaza's hiaticola, from hiatus and colere, standing for $\chi \alpha \rho \alpha \delta \rho t o ́ \varsigma$ at $615 \mathrm{a} 1$, was misinterpreted as diminutive and became Charadrius hiaticula in the modern bird nomenclature). Moreover, Gaza did coin a neologism from rubus 'bramble', but it is a completely different bird name:

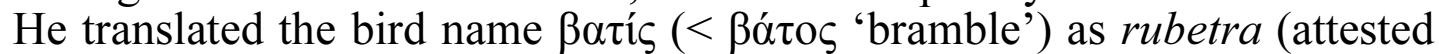
just once, Arist. Hist. an. 592b17, not to be confused with $\beta a \tau i$ 's 'skate, ray'), registered in Jobling 2010: 339, too. 
interpretation is possible. Gaza could have imagined two Greek names, so to say 'red-tail' and 'ruby-rump', standing for two birds that both had reddish feathers but, in their winter and summer plumage, were still different in the hue of their breast and tail feathers. As far as I can judge, the above arguments for the interpretation of rubecula as a compound with cülus are stronger than the counterargument provided by the passage at lines $632 \mathrm{~b} 27-$ 30. Indeed, the function of Gaza's interpolations was often rhetorically decorative rather than clarifying (cf. examples in Perfetti 1995: 274-280). In this case, the addition of "pectoris and caudae", absent in the Greek original, may be a mere amplificatio.

Since the only source for the allegedly existing *-cilla is Varro's explanation of motacilla, Gaza was prudent enough to avoid applying it while naming other creatures than birds, even if the root 'tail' could be surmised in the Greek word. Thus, he rendered $\mu \varepsilon \lambda \alpha^{\prime}$ ovopos (a fish, 591a15) as oculata $^{16}$, i $\pi \pi 0 v \rho o \varsigma$ (a fish, 543a22-

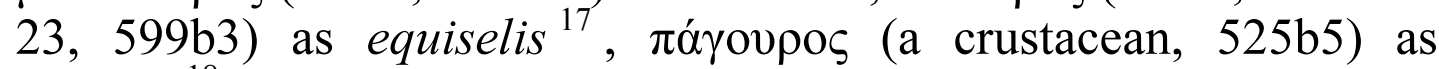
pagurus $^{18}$, a'خ '̇oupos ('cat', 540a10, 580a23, 612b15) as felis, and

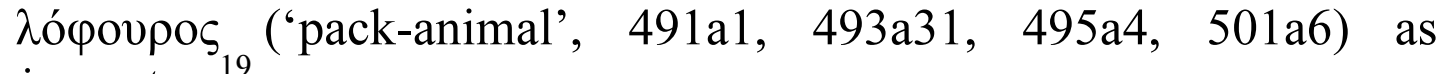
iumentum ${ }^{19}$.

No other animal names derived from *-cilla or cūlus have been detected in Gaza's translation.

The word verticillus, or verticilla, that Gaza uses for rendering the Greek insect name $\sigma \varphi o v \delta v ́ \lambda \eta(542 \mathrm{a} 10,604 \mathrm{~b} 19,619 \mathrm{~b} 22)$ is attested in classical sources (e.g. Plin. $H N 37,37,2)$ and is a calque,

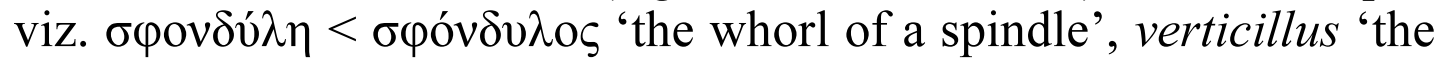
whorl of a spindle'. Gaza was the first though to apply this Latin word to an animal.

The following animal names in Gaza's text contain the component -cul-:

1) with the $-c$ as a part of the root and the diminutive suffix $-u l-$ : lumbriculus ( $<$ lumbricus 'worm'), falcula $(<$ falx 'sickle', a calque

\footnotetext{
${ }^{16}$ The reason of this identification with the word attested in Pliny is still to be investigated.

${ }^{17}$ On Gaza's use of this word, attested as a variant reading in Plin. $H N 18$, 259, 6-9, I am currently preparing a separate study.

${ }^{18}$ This transliteration is present in Pliny (in many other cases, Gaza substituted the Greek-sounding transliterations by neologisms, even in cases when they are present in Pliny and other classical Latin authors, as he

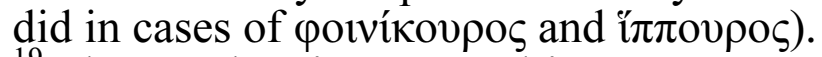

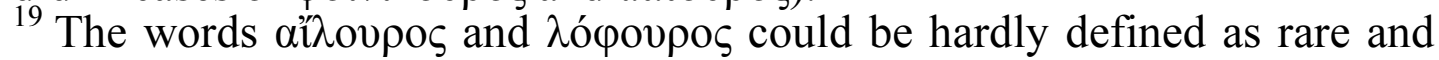
were, therefore, easily rendered with well-known Latin words.
} 
of $\delta \rho \varepsilon \pi \alpha v i ́ \varsigma<\delta \rho \varepsilon \pi \alpha ́ v \eta$ 'sickle', a bird, 487b27), halecula $(<(\mathrm{h})$ alec, a fish, 569a18, for $\mu \alpha i v i ́ \delta 10 v<\mu \alpha i v i ́ s$, the latter regularly rendered by Gaza as alec), graculus (a fish, 543a31, named after the bird graculus as a calque of the Greek fish name коракĩvo $<\kappa$ <ó $\alpha \xi$; for the etymology of graculus, see De Vaan 2007: 268; Ernout Meillet 2001: 279);

2) with the diminutive suffix -cul-: pectunculus (cf. pecten

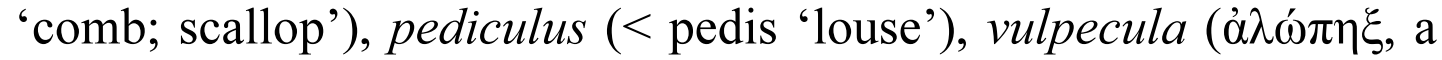
fish, 565b1, 566a31, and a bat, 490a7), canicula ( $\sigma \kappa v ́ \lambda$ iov, a fish,

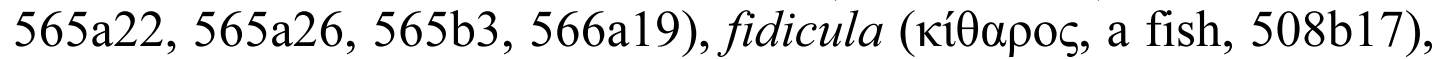
musculus ( Pliny's fish name musculus: HN 9, 186, 2; 11, 165, 6), bucula (< bos; for Boídiov, 522b14) ${ }^{20}$, tinnunculus (a diminutive, from verb tinnio; attested in classical sources; used by Gaza for

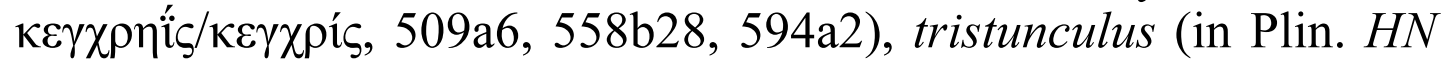
$10,109,2$, a corrupted reading of the previous, used by Gaza also

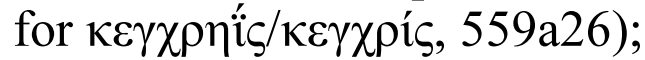

3) other: cuniculus 'rabbit' (well attested in classical sources, of unclear etymology, perhaps Iberian, Ernout Meillet 2001: 157).

All these word, including those coined by Gaza, clearly could not have been derived from cülus. Thus, apparently only Greek bird names with a component meaning 'rump' or 'tail' in their structure were rendered by Gaza with neologisms derived from *-cilla or cūlus.

\section{The afterlife of rubecula, rubicilla, ruticilla, albicilla, and} albicula

\subsection{Rubecula}

In his Cornu copiae, conceived as a commentary to Martial but in fact a massive encyclopedia, or dictionary, one of the important sources of first Renaissance lexicographers (cf. Abbamonte 1998;

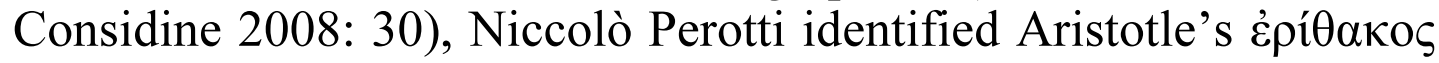
with the robin-redbreast: "Avis est, quam vulgo pectus rubeum

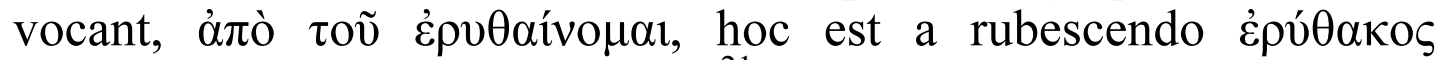
dicitur" (Perotti 1489: f. 103v) ${ }^{21}$. The vernacular name pectus

\footnotetext{
${ }^{20}$ Gaza spells buccula, but his use of geminates is generally inconsistent.

21 "There is a bird that is called in the vernacular redbreast; it is called

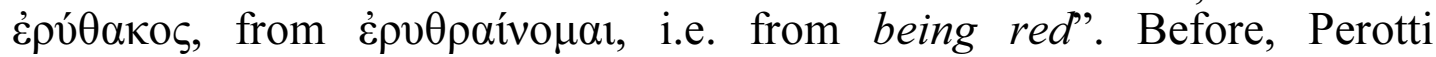

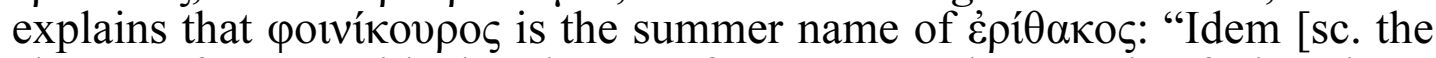
change of name with the change of season] erythacus [sic] facit. Hieme enim erythacus est, phenicurus [sic] aestate. Avis est quam vulgo...".
} 
rubeum is clearly a reference to the Italian pettirosso 'robinredbreast'. Perotti's identification seems absolutely deliberate, or perhaps stimulated by Gaza's addition of pectore in Arist. Hist. an.

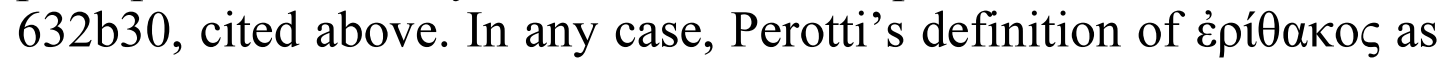
'robin-redbreast' was adopted in one of the most popular Latin dictionares of the sixteenth-century, reprinted many times (cf. Considine 2008: 29), namely that of Ambrogio Calepino (Calepino 1502: f. $\int[7] \mathrm{v}$, s. v. erythacus).

In 1544, the ornithologist William Turner, who was the first to attempt a systematic identification of ancient bird names with modern vernacular ones, adopted Perotti's assumption in his Avium praecipuarum, quarum apud Plinium et Aristotelem mentio est,

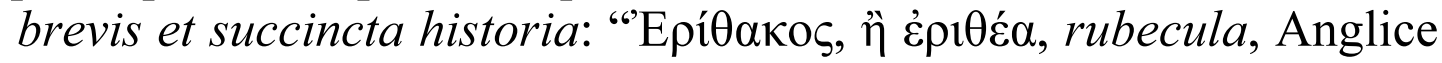
a robin redbreste, Germanice eyn rotbrust oder eyn rotkelchen" (Turner 1544: f. H [8]r) ${ }^{22}$.

Turner's decision was adopted in the ornithological volume of Conrad Gessner's milestone Historia animalium ${ }^{23}$ and eventually became the standard Latin denomination of the robin-redbreast. Therefore, in 1758 tenth edition of Linné's Systema naturae, the edition underlying the modern binary nomenclature of animals, the word rubecula was adopted for robin-redbreast, placed by Linné in the genus Motacilla, namely Motacilla rubecula (Linnaeus, 1758). Later on, in the appendix to the first volume of his Leçons d'anatomie comparée, George Cuvier suggested a new classification of the animals. There, he reduced the volume of the genus Motacilla, introducing new genera for the birds that had been considered in the genus Motacilla before. Thus, he introduced a new genus, Erithacus, which included the species Erithacus rubecula. The latter binary name is still valid in today's scientific nomenclature.

${ }^{22}$ On Turner, see Harrison 1954; Stresemann 1975: 13-16; Bäumer 1991: 333-335, as well as A. H. Evans' introduction in Turner 1903. Turner's treatise was the first reference book in ornithology. Gilbertus (Gybertus) Longolius' Dialogus de avibus et earum nominibus Graecis, Latinis et Germanicis was published in the same year 1544, posthumously, by Turner, who was the author's friend (Longolius 1544). Longolius' book, apart from being written in the form of a dialogue, is generally less systematic, discusses less bird names, and its impact on the natural science can be hardly compared with that of Turner's book (cf. Stresemann 1975: 14; Bäumer 1991: 333).

${ }^{23}$ On Gessner's encyclopedic work, see e.g. Riedl-Dorn 1989; Friedrich 1995; Enenkel 2007. For the ornithological volume, see especially Springer, Kinzelbach 2009. 


\section{2. Rubicilla}

William Turner's book contains a chapter entitled De rubicilla, starting with the following list of synonyms: " $\pi v \rho \rho o v ́ \lambda \alpha \varsigma$, rubicilla, Angli(ce) a bulfinche, Germa(nice) eyn blodtfinck". Indeed, Turner understood Gaza's rubicilla as the rendering of $\pi v \rho \rho o v i \lambda \alpha$, the reading he knew from the editions of the Greek text. Apparently he considered both the Greek and the Latin words diminutives and deliberately, just on the basis of the color underlying their etymology, identified them with the bullfinch: "Ego, nominis etymologiam secutus, rubicillam Anglorum bulfincam et Germanorum bloudvincam esse conjicio" (Turner 1544: f. I 1v$2 r)^{24}$. Turner's identification was taken over by Gessner in the respective chapter, entitled De rubicilla sive Pyrrhula (Gessner 1555: 701-702).

Indeed, thanks to Turner, the transliteration of $\pi v \rho \rho o v i \lambda \alpha \varsigma$, Pyrrhula, is now the valid name of the genus bullfinches. The word rubicilla, however, appears in modern nomenclature, since at least 1775 , as the specific epithet in the name of the great rosefinch, Carpodacus rubicilla (Güldenstädt, 1775), a passerine spread in the Caucasus, as well as in certain regions Asia ${ }^{25}$, unknown in Western Europe. When did the word rubicilla change its meaning? Its story is similar to that of the word silvia which was understood as 'robinredbreast' since Turner and reinterpreted in the eighteenth century as 'warbler' (on it, see Vorobyev 2018: 254-258).

After the establishment of the Linnaean system, the bullfinch was known as Loxia pyrrhula (Linné 1758: 171-172; cf. Linné 1766, vol. 1: 300), so the word rubicilla remained its void synonym, without any use in the taxonomy. That is why, similarly to how the word silvia was recycled by Jacob Theodor Klein (Vorobyev 2018: 257), rubicilla was recycled by the Riga-born naturalist Johann Anton Güldenstädt when, after his 1768-1775 journey to the Caucasus, he published the first scientific description of the great rosefinch. He defined it as a new species in Linné's genus Loxia ${ }^{26}$ and introduced for it the name Loxia rubicilla. He could do so, for the word rubicilla, at that time, was not assigned any denotatum in the nomenclature. In the description of this species, Güldenstädt

\footnotetext{
24 "As for me, I guess, following the etymology of the word, that rubicilla is the bullfinch of the English and the Blutfink of the Germans".

${ }_{25}^{25}$ For the range map, see Clement 2020.

${ }^{26}$ He used the twelfth edition of Linné's Systema naturae (Linné 17661768).
} 
mentioned the bullfinch under the name pyrrhula, when he remarked that the voice of the great rosefinch (Loxia rubicilla) was similar to that of the bullfinch (pyrrhula) (Güldenstädt 1775: 463465).

Later on, exactly as it happened with Linné's genus Motacilla, described above, Linné's genus Loxia was split. The genus Pyrrhula was separated from it by Mathurin-Jacques Brisson (Brisson 1760: 308) and Carpodacus by Johann Jakob von Kaup (Kaup 1829: $161)^{27}$, while only the crossbills remained in the genus Loxia ${ }^{28}$.

\section{3. Ruticilla}

The fortune of the word ruticilla was similar. Apparently, no modern scholar has ever doubted that Aristotle understood a

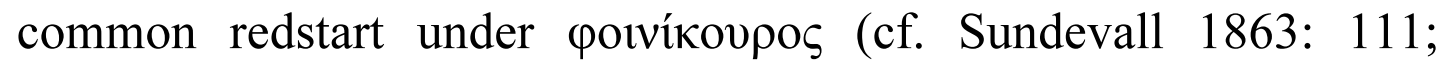
Thompson 1895: 182).

William Turner, as we said, accepted Perotti's deliberate identification of épí $\theta \alpha \kappa o \varsigma$ with robin-redbreast. Therefore, analyzing the passage Arist. Hist. an. 632b27-30, quoted in the section 1.3 above, and knowing from his own field observations that robinredbreast did not obtain reddish tail-feathers in summer, Turner stated that poivíkoupos could not be the name of the śí⿴囗⿱一一) summer garment. Instead, he introduced to the ornithological literature the identification of pouvíkovpos with the common

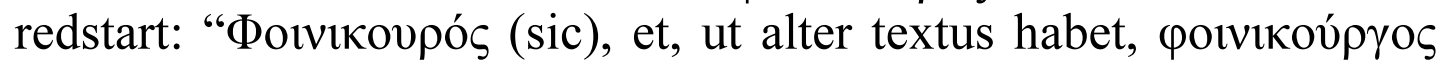

\footnotetext{
${ }^{27}$ Kaup explains there how he coined that name: "Von $\kappa \alpha \rho \pi$ ó $\varsigma$, Frucht, und

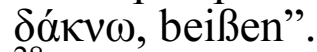

28 This actually corresponds to the original meaning of the name Loxia, a word coined by Gessner for denoting the crossbill, since he could not find any classical Greek or Latin name for it. Indeed, Gessner begins the chapter entitled De Loxia as follows "Hanc avem lingua Germanica Krützvogel, id est cruciatam, vel Krummschnabel, id est curvirostram appellat, Illyrica krziwonoska, id est nasicurvam, a rostra figura utraque. Sola enim haec avium summas rostri partes ac mucrones invicem transponit ac decussat, quare nos loxian ab obliquitate nominavimus" (Gessner 1555: 568). The etymology of Gessner's neologism, viz. from the Greek $\lambda$ o $\xi_{\text {ó }} \varsigma$ 'slanting, crosswise, oblique', is evident; yet, nobody in the modern literature, as far as I can judge, has acknowledged Gessner's authorship of this name (e.g. Springer and Kinzelbach erroneously explain it as an ancient name: "Der antike Name loxia (lat.) ist seit Linnaeus (1758) der gültige Gattungsname der Kreuzschnäbel" (Springer, Kinzelbach 2009: 372); Jobling provides the Greek etymology but, again, does not refer to Gessner (Jobling 2010: 231; Jobling 2020, s.v. Loxia and loxia). — On today's volume and vernacular names of the genera Carpodacus, Pyrrhula, and Loxia, see Boehme, Flint 1994: 436, 433, 435; Collar, Newton, Bonan 2020.
} 
(sic), Plinio phoenicurus, Gazae ruticilla, Anglice a rede tale, Germanice eyn rot stertz" (Turner 1544: f. H [8]r) ${ }^{29}$. This identification was easy, for the name of the common redstart in the European vernaculars was similar: 'redstart', 'redtail', 'Rotschwanz', 'codirosso' etc. (cf. Gessner 1555: 699).

In the concurrence between phoenicurus and ruticilla, considered synonyms since Turner, the Latin one seemed winning. Conrad Gessner included both names in the title of the respective chapter in his Historia animalium, but ruticilla was first (De ruticilla seu phoenicuro), moreover the large running titles included only De ruticilla (Gessner 1555: 699-701). This was reflected in the major seventeenth-century reference books in zoology, too. Namely, Francis Willoughby preferred the variant ruticilla and entitled the

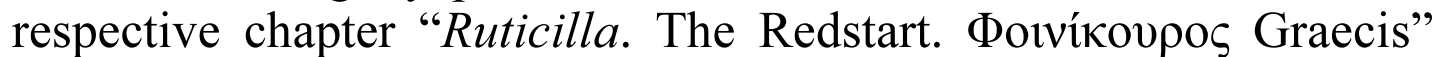
(Willoughby 1676: 159); John Ray's posthumous Synopsis methodica avium et piscium also speaks of the redstart as of ruticilla (Ray 1713: 78). Still, nowadays, the common redstart is known under the scientific name Phoenicurus phoenicurus (Linnaeus, 1758). How did it happen and what was the eventual fortune of the word ruticilla?

In North America, a bird was observed that seemed similar to the common redstart to Mark Catesby, who, in his bilingual EnglishFrench Natural history of Carolina, Florida and the Bahama Islands, denoted that bird as Ruticilla Americana (also, the redstart in English and, in French, Le rossignol de muraille de l'Amérique ${ }^{30}$ ). Catesby's description is entitled in Latin, Ruticilla Americana, and begins as follows: "This bird is about the size of, or rather less than, our redstart" (Catesby 1729-1732: 67). George Edwards, in his 1743 Natural history of uncommon birds, approves of Catesby's denomination: "He calls it the redstart, whose example I have taken, as I think the name very proper". Edwards' chapter is, indeed, entitled The small American redstart (Edwards 1743: 80). Now, Linné, in the 1758 edition of his Systema naturae, names the

\footnotetext{
${ }^{29}$ In three manuscripts of the Hist. an., according to the apparatus in David Balme's 2002 edition, the word appears in the form poivikoṽ $\rho$ or instead of poivíkovpou, both at $632 \mathrm{~b} 28$ and $632 \mathrm{~b} 29$ (cf. n. 6 above). The readings in Pliny, in Hesychius, and in the Geoponica are unambiguous. Still, in the Aldine princeps of the Hist. an., the reaing in -oṽ $\gamma$ os was adopted and persisted apparently until Camus' edition (Aristotle 1783, vol. 1: 638 and 756) who reads -ovpos.

${ }^{30}$ Le rossignol de muraille is one of the French denominations of the common redstart.
} 
American bird described by Catesby and Edwards Motacilla ruticilla, apparently based on Catesby's naming (Linné 1758: 186). As for the Old-World redstart, i. e. common redstart, Linné calls it Motacilla phoenicurus, following not the examples of Willughby and Ray, who call it ruticilla, but that of a lesser-known naturalist Johann Leonhard Frisch who describes four Old-World kinds of the redstart, calling them all phoenicurus (Frisch 1734-1739: f. 20r). Thus, Linné decided to leave the name ruticilla to the American redstart that already had been registered under that Latin name by Catesby. As for the common redstart, Linné assigned to it the remaining name phoenicurus.

Therefore, it was Linné's decision to designate the common redstart with the Greek name and the American redstart with the Latin one. The distribution of species between genera, as it also happened in case of Motacilla and Loxia, changed due to the development of systematic, but the specific epithets remained the same. Indeed, for the common redstart, the currently valid name is Phoenicurus phoenicurus, for the American redstart it is Setophaga ruticilla. Both scientific names bear the reference "Linnaeus, 1758" in brackets.

\section{4. Albicilla and albicula}

As for albicilla, in the chapter De aquila, Turner quotes Gaza's translation of Arist. Hist. an. 618b9, and adds a comment in which, using the name pygargus, he blames certain "Germanorum literatores" who identified pygargus with German Trappe. I was not able to identify the German author Turner criticizes but, what is important, Turner is sure that the German Trappe 'bustard' should correspond to Aristotle's $\tau \dot{\varepsilon} \tau \rho 1 \xi$, while for the pygargus he ventures another identification: "Pygargus Anglorum lingua, nisi fallar, erna vocatur", and provides in margin the English gloss "an erne" (Turner 1544: f. B [6]r). Since no argumentation is provided, we must conclude that Turner's identification was based on the etymology of the Greek word and the white tail of the bird he knew as erne, i.e. white-tailed eagle, or sea eagle. Gessner takes over Turner's identification, also cites Gaza's variant albicilla but follows Turner in using pygargus as the main denomination (the respective chapter is entitled De pygargo, the same is the text of the 
running title, Gessner 1555: 199) ${ }^{31}$. Modern nomenclature follows Turner's identification, namely the word albicilla denotes the whitetailed eagle (sea-eagle), not the bustard: Haliaetus albicilla (Linnaeus, 1758).

The word pygargus, yet, denotes a smaller bird of prey, a harrier: Circus pygargus (Linnaeus, 1758), today known in English as Montagu's harrier. The reason of this denomination is the alternative identification of Aristotle's $\pi$ vo $\alpha \rho \gamma o \varsigma$, suggested in 1555 by the French zoologist Pierre Belon. His L'histoire de la nature des oiseaux was printed the same year when the ornithological volume of Gessner's Historia animalium appeared. The two works were written independently, as Gessner himself notices in the end of his preface $^{32}$. What is important for us now is that Gessner made extensive use of Turner's 1544 treatise, while Belon used it irregularly, if at all ${ }^{33}$. Thus, nothing prevented Belon from

${ }^{31}$ For a brief overview of later authors who used this name, see Jobling 2010: 38, who acknowledges Gaza's authorship, which is not the case in numerous other neologisms of Gaza's coinage.

32 "Petri Bellonii Cenomani de avibus librum Lutetiae hoc ipso tempore excudi audio, qui forte iam absolutus est, ad nos quidem nondum pervenit" ("I hear that right now a book on birds by Pierre Belon of Le Mans is being printed in Paris, perhaps it is already finished but it has not yet arrived here", Gessner 1555: f. a [6]r).

${ }^{33}$ Whereas Gessner is always very accurate in providing the sources of the information he cites, Belon is not. Moreover, Gessner and Turner were friends (cf. Harrison 1954: 3; Stresemann 1975: 14) and Gessner willingly acknowledges this or that apt idea of the English naturalist. Belon, on the contrary, never names Turner's treatise explicitly. Once, he mentions Turner merely as the source of a taxidermic specimen of a canary ("le serin") that he, Belon, was once shown by a certain Flemish Antonius Martinellus in Padua: "Mais M. Antoine Martinellus flamand nous en montra un sec et salé à Padoue avant notre départ, disant qu'un sien ami M. Turnerus médecin anglais le lui avait envoyé" (Belon 1555: 355; orthography modernized). This passage could mean that Belon did not know Turner's ornithological book at all; still, Turner's output seems to be mentioned, apparently just once, concerning a species of the heron: "Il est assez commun par nos rivages, ayant témoins modernes qui ont écrit qu'on le voit aussi en Angleterre. De cette diligence ne voulons frustrer le devoir dû à monsieur Tournerus savant médecin" (Belon 1555: 191; cf. Turner 1544: f. C [1]v). Once more, Belon speaks of "certain modern authors", while probably criticizing Turner: "L'on trouve quelques modernes qui ont voulu dire qu'il y eût plusieurs espèces de cet oiseau et, en amenant deux ou trois espèces, les ont tous nommé tyranni. Mais l'on peut prouver $<\ldots>$ qu'il en est autrement" (Belon 1555: 345; it was Philippe Glardon, in Belon 1997: 467, who identified Turner 1544: f. I 5v as the source cited in this passage). The character of Belon's use of Turner's book should be 


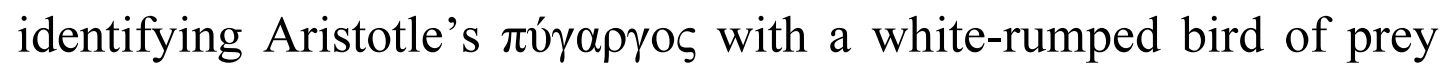
different from the sea eagle, namely with Jean-le-Blanc, or oiseau Saint-Martin. Today these two French names designate different species, short-toed snake eagle (Circaëtus gallicus) and hen harrier (Circus cyaneus), but for Belon they stood for one. Belon's bird book was of no less authority than Gessner's. Indeed, Francis Willoughby, in his Ornithologia, published in 1676, posthumously, by John Ray, identifies Belon's pygargus with the hen harrier (Willoughby uses a now outdated form henharrow). It is no wonder that John Ray himself, in his 1713 Synopsis methodica avium et piscium, which was an important ornithological source for Linné, used the word pygargus twice, namely once as a synonym of albicilla, meaning the sea eagle (Ray 1713: 7, in the section Aquilae), and once as a denomination of a white-rumped harrier, now known as Montagu's harrier (Ray 1713: 17, in the section Accipitres) $)^{34}$.

As for albicula, both the reason of its appearance in Gaza's translation and its denotatum remained obscure, so it enjoyed less attention than albicilla in the early modern time. Turner does not mention it. Gessner is puzzled why Gaza mentions albicula: "Theodorus Gaza in Historia animalium ex Aristotele translata lib(ro) 8 cap(ite) 3 albiculam numerat inter eas aves quae circa lacus

clarified but, apparently Belon did use it occasionally. Still, he does not mention Turner's identification of $\pi u \rho \rho o v i \lambda \alpha \varsigma$ with the bullfinch; for Belon,

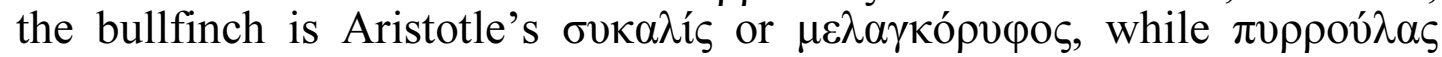
stands for 'robin-redbreast' and is a synonym of غ́pi $\theta \alpha \kappa o \zeta$, whereas Turner,

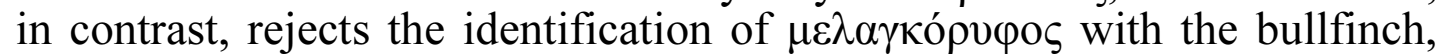
suggesting the black-cap instead (Belon 1555: 359; 348; Turner 1544: f. C

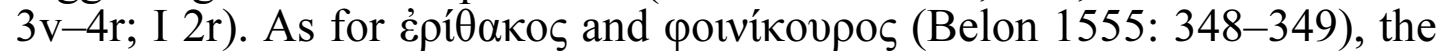
identifications proposed by Belon coincide with those of Turner, but it should not mean that Belon's choice was based on that of Turner. Indeed,

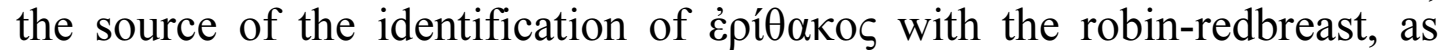
shown above, was Niccolò Perotti's Cornu copiae, adopted in Calepino's popular dictionary. As for the identification of povvíkovpos with the common redstart, the latter is, apparently, the most common passerine bird with a reddish tail in Europe, so it is no wonder that Belon's identification coincides with that of Turner. - On Belon's book, see Bäumer 1991: 335344; Philippe Glardon's introduction in Belon 1997. For a comparison of Turner's, Belon's, and Gessner's methods in their ornithological reference books, see Stresemann 1975: 13-21; Bäumer 1991: 344-345.

${ }^{34}$ The distinction between the hen harrier, Circus cyaneus (Linnaeus, 1758), and Montagu's harrier, Circus pygargus (Linnaeus, 1766), was introduced later. 
et fluvios victum quaerunt, ubi in Graecis nostris codicibus excusis nihil quod huic vocabulo respondeat invenio" (Gessner 1555: 208) ${ }^{35}$. Agostino Nifo, in his posthumously issued 1546 commentary to Aristotle's Historia animalium, suggested that Gaza's Greek Vorlage could have read $\lambda \varepsilon v \kappa o ́ s$ here, omitted in the printed

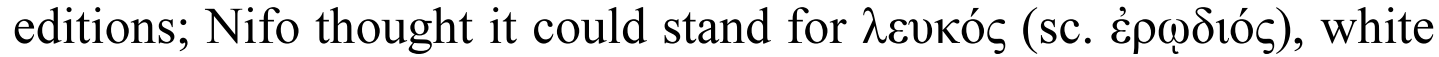
heron (Aristotle 1546: 230). Still, the white heron is mentioned shortly before in the same list of birds, wherefore Gessner 1555: 208 rejected Nifo's hypothesis ${ }^{36}$. As shown above, Gaza's albicula in

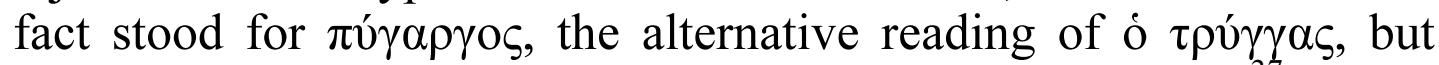
this varia lectio appeared in print in 1811 for the first time ${ }^{37}$. These textual problems and Gessner's perplexity about the origin of Gaza's albicula led to its failure to settle in the nomenclature. Unlike the similar cases of silvia, rubicilla, ruticilla, and albicilla, the word albicula was never used in the binary nomenclature of birds.

Pierre Belon, apparently based on Gaza's bird names albicilla and albicula and considering them mere diminutives rather than compounds, reused them in his book on fishes. In a chapter entitled Leuciscus, Belon identified the fish name $\lambda \varepsilon v \kappa i ́ \sigma \kappa o s$, attested in Hicesius, with several modern vernacular names. Even though in the text he constantly denoted that fish by the transliteration leuciscus, he deemed important providing a truly Latin equivalent. Namely, the full chapter title reads: Leuciscus, hoc est Albicilla seu Albicula (Belon 1553: 313), cited by Gessner: "De eodem Bellonius, qui leuciscum simpliciter hunc pisciculum nominat et Latine inquit albicillam vel albiculam dici posse" (Gessner 1558: 31). Still, the word albicula reached the binary nomenclature neither as a bird, nor as a fish name.

35 "Theodore Gaza, in his translation of Aristotle's Historia animalium, book 8, chapter 3, mentions albicula among those birds that search for food by lakes and rivers, at which place I can find nothing in our Greek printed books that would correspond to this word)"; cf.: "...albicula (quod huic nomen in exemplaribus nostris Graecis respondeat nullum est)" (Gessner 1555: 593).

${ }^{36}$ Belon, on the contrary, repeated Nifo's suggestion, without naming Nifo as his source though (Belon 1555: 191, 195). Julius Caesar Scaliger was also puzzled why Gaza had added albicula ("ascripsit albiculam sed in nostro codice deerat", Aristotle 1619: 891). — On Nifo's commentary, see Perfetti 1996; Perfetti 2000.

${ }^{37}$ Johann Gottlob Schneider was apparently the first to discuss this textual problem. In his Greek text, he opted for the reading $\pi$ í $\gamma \alpha \rho \gamma o \zeta$, adding " $\kappa \alpha i$

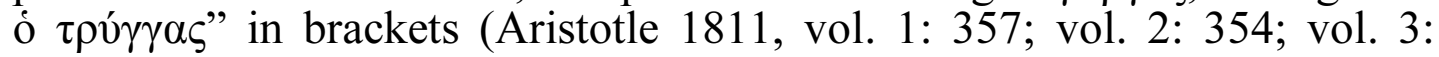
596). 


\section{Conclusions}

Theodore Gaza's neologisms albicilla, rubicilla, and ruticilla, rather than diminutives, are derived from a phantom word *-cilla 'rump, bird-tail'; his neologisms albicula and rubecula are, most probably, derived from cülus 'the posteriors, fundament' and should be, therefore, pronounced albicūla and rubecūla, which is relevant for the latter, denoting the robin-redbreast in today's scientific nomenclature (Erithacus rubecula).

As the analyzed cases demontstrate, the identifications proposed in the first modern reference book in ornithology, William Turner's Avium praecipuarum, quarum apud Plinium et Aristotelem mentio est, brevis et succincta historia, were willingly taken over in Conrad Gessner's authoritative Historia animalium, whence, through a chain of intermediary reference books, they influenced the lexical choice of eighteenth-century authors responsible for the elaboration of modern binary nomenclature. The presence of a transliterated Greek word alongside with its Latin translation in the zoological reference books often led to the situation when just one of such synonyms was taken over in the nomenclature, while the second one remained without denotatum. These void names were reused later for designating newly introduced taxa.

\section{References}

Abbamonte 1998: Abbamonte, G. Le ultime ricerche sull'attività lessicografica di Niccolò Perotti. Roma nel Rinascimento, 45-58.

Aristotle 1476: Gaza, T. (transl.). Aristoteles. De animalibus. Venice (GW 2350).

Aristotle 1497: Aldus Manutius (ed.). Aristoteles. Opera. Vol. 3. Venice (GW 2334).

Aristotle 1546: Gaza, T. (transl.), Nifo, A. (comm.). Expositiones in omnes Aristotelis libros de historia animalium, de partibus animalium et earum causis, ac de generatione animalium. Venice.

Aristotle 1619: Scaliger J. C. (ed., transl., comm.). Aristoteles. Historia de animalibus. Toulouse.

Aristotle 1783: Camus, A.-G. (ed., transl., comm.) [Histoire des animaux d'Aristote]. Vol. 1. Histoire des animaux d'Aristote avec la traduction française. Vol. 2. Notes sur l'histoire des animaux d'Aristote. Paris.

Aristotle 1811: Schneider J. G. (ed., comm., rev.). Scaliger J. C. (transl.). Aristoteles. De animalibus historiae. Vols. 1-4. Leipzig.

Aristotle 1994: Hünemörder C. (ed.). Aristoteles. De animalibus libri XIX in der Übersetzung des Michael Scotus. Nach der Handschrift Rom, Bibliotheca Apostolica Vaticana, Chigi E VIII 251 (s. XIII), fol. 1ra-108rb, mit Textkorrekturen aus den Handschriften Nürnberg, 
Stadtbibliothek, Cent. VI 10 und Pisa, Bibliotheca di Santa Caterina, Cod. 11. Buch I-XIV. [Eichstätt-Munich].

Aristotle 2002: Balme, D. M. (ed.). Aristotle. Historia animalium. Vol. 1: Books I-X: Text. Prepared for publication by Gotthelf, A. Cambridge.

Aristotle 2018: Filius, L. S. (ed.) The Arabic version of Aristotle's Historia animalium. Book I-X of Kitāb al-Hayawān. Leiden-Boston.

Arnott, W. G. 2007: Birds in the ancient world from A to Z. London; New York.

Bader, F. 1962: La formation des composés nominaux du latin. Besançon.

Bäumer, Ä. 1991: Geschichte der Biologie. Vol. 2: Zoologie der Renaissance - Renaissance der Zoologie. Frankfurt a.M. etc.

Beekes, R. S. P. 2010: Etymological dictionary of Greek. Vols. 1-2. Leiden; Boston.

Belon, P. 1553: De aquatilibus. Paris.

Belon, P. 1555: L'histoire de la nature des oyseaux. Paris.

Belon, P. 1997: Glardon, Ph. (introd. and comm.). Belon, P. L'histoire de la nature des oyseaux (facsimile edition of Belon 1555). Genève.

Berger, F. 2005: Die Textgeschichte der Historia Animalium des Aristoteles. Wiesbaden.

Beullens, P., Gotthelf, A. 2007: Theodore Gaza's translation of Aristotle's De animalibus: content, influence and date. Greek, Roman and Byzantine studies 47. 469-513.

Beullens, P. 2008: Aristotle, his translators, and the formation of ichthyologic nomenclature. In: M. Goyens, P. De Leemans, A. Smets (eds.), Science translated. Latin and vernacular translations of scientific treatises in Medieval Europe. Leuven. 105-122.

Boehme, R. L., Flint, V. E. 1994: Pyatiiazychnyi slovar' nazvanii zhivotnykh. Ptitsy, Latinskii-russkii-angliiskii-nemetskii-frantsuzskii [A five-language dictionary of animal names. Birds. Latin, Russian, English, German, French]. Moscow. Бёме, Р. Л., Флинт, В. Е. 1994: Пятиязычный словарь названий жсвотных. Птицы. Латинский-русский-английский-немецкий-франиузский. М.

Brisson, M.-J. 1760: Ornithologie, ou méthode contenant la division des oiseaux en ordres, sections, genres, espèces et leurs variétés. Vol. 3. Paris.

Calepino, A. 1502: Dictionarium. Reggio [Emilia].

Catesby, M. 1729-1732: The natural history of Carolina, Florida and the Bahama Islands. Vol. 1. London.

Chantraine, P. ${ }^{2}$ 1999: Dictionnaire étymologique de la langue grecque. Histoire des mots. Paris.

Clement, P. 2020: Great Rosefinch (Carpodacus rubicilla). In: HBW (https://www.hbw.com/node/61402, accessed on 05.01.2020)

Collar, N., Newton, I., Bonan, A. 2020: Finches (Fringillidae). In: HBW (https://www.hbw.com/node/52376, accessed on 05.01.2020).

Considine, J. 2008: Dictionaries in Early Modern Europe. Lexicography and the making of heritage. Cambridge.

Dahlmann, H. 1973: Varroniana. In: Temporini, H. (ed.). Aufstieg und Niedergang der römischen Welt. Geschichte und Kultur Roms im 
Spiegel der neueren Forschung. I. Von den Anfängen Roms bis zum Ausgang der Republik. Vol. 3. Berlin. 3-25.

De Vaan, M. 2008: Etymological dictionary of Latin and the other Italic languages. Leiden; Boston.

Dittmeyer, L. 1902: Untersuchungen über einige Handschriften und lateinische Übersetzungen der Aristotelischen Tiergeschichte. Programm des Königlichen Neuen Gymnasiums zu Würzburg für das Studienjahr 1901/02. Würzburg.

Du Cange, Ch. [et al.] 1883-1887 ( $\left.{ }^{1} 1678\right)$ : Glossarium mediae et infimae latinitatis. Niort (http://ducange.enc.sorbonne.fr/, accessed on 24.11.2019)

Edwards, G. 1743: A natural history of uncommon birds and of some other rare and undescribed animals. Vol. 1. London.

Enenkel, K. A. E. 2007: Zur Konstruierung der Zoologie als Wissenschaft in der Frühen Neuzeit: Diskursanalyse zweier Großprojekte (Wotton, Gesner). In: Enenkel, K. A. E., Smith, P. J. (eds.). Early modern zoology. The construction of animals in science, literature and the visual arts. Leiden; Boston. 15-74.

Ernout, A., Meillet, A. ${ }^{4} 2001$ : Dictionnaire étymologique de la langue latine. Histoire des mots. Paris.

Friedrich, U. 1995: Naturgeschichte zwischen artes liberales und frühneuzeitlicher Wissenschaft. Conrad Gessners Historia animalium und ihre volkssprachliche Rezeption. Tübingen.

Frisch, J. L. 1734-1739: Vorstellung der Vögel in Teutschland. Berlin.

Frisk Hj. Griechisches etymologisches Wörterbuch. Vols. 1-3. Heidelberg, 1960-1972.

Gessner, C. 1555: Historia animalium. Vol. 3: De avium natura. Zurich.

Gessner, C. 1558: Historia animalium. Vol. 4: De piscium et aquatilium animantium natura. Zurich.

Glare, P. G. W. 22012: Oxford Latin dictionary. Oxford.

Grimm, J. 1826: Deutsche Grammatik. Pt. 2. Göttingen.

Güldenstädt, J. A. 1775: Sex avium descriptiones. Novi commentarii Academiae Scientiarum Imperialis Petropolitanae 19 (1774), published in 1775. Saint Petersburg. 463-475.

Harrison, Th. P. 1954: William Turner, naturalist and priest. The University of Texas Studies in English 33, 1-12.

HBW 2020: del Hoyo, J. et al. (eds.). Handbook of the birds of the world alive (https://www.hbw.com, accessed on 02.03.2020).

Helander, H. 2014: On neologisms in Neo-Latin. In: Ford, P., Bloemendal, J., Fantazzi, Ch. (eds.), Brill's encyclopaedia of the Neo-Latin world. 2 vols. Leiden; Boston. Vol. 1, 37-54.

Jobling, J. A. 2010: The Helm dictionary of scientific bird names. From Aalge to Zusii. London.

Jobling, J. A. 2020: Key to Scientific Names in Ornithology. In: HBW (https://www.hbw.com/dictionary/key-to-scientific-names-inornithology, accessed on 02.03.2020).

Kaup von, J. J. 1829: Skizzirte Entwickelungs-Geschichte und natürliches System der europäischen Thierwelt. Vol. 1. Darmstadt.

Leumann, M. 1977: Lateinishe Laut- und Formenlehre. Munich. 
Liddell, H. G., Scott, R., Jones, H. S. ${ }^{9} 1940$ : A Greek-English lexicon. Oxford (https://logeion.uchicago.edu, accessed on 02.03.2020).

Linné von, C. ${ }^{10} 1758$ : Systema naturae. Vol. 1. Stockholm.

Linné von, C. ${ }^{12} 1766-1768$ : Systema naturae. Vols. 1-3.

Longolius, G. 1544: Dialogus de avibus et earum nominibus Graecis, Latinis et Germanicis. Cologne.

Monfasani, J. 1999: The Pseudo-Aristotelian Problemata and Aristotle's De Animalibus in the Renaissance. In: Grafton, A., Siraisi, N. (eds.). Natural Particulars. Nature and the disciplines in Renaissance Europe. Cambridge [Mass.]-London. 205-247.

Niedermann, M. 1897: E und $\breve{l}$ im Lateinischen. Ein Beitrag zur Geschichte des lateinischen Vocalismus. Darmstadt (Diss. Basel).

Perfetti, S. 1995: 'Cultius atque integrius'. Teodoro Gaza, traduttore umanistico del De partibus animalium. Rinascimento 35. 253-286.

Perfetti, S. 1996: Metamorfosi di una traduzione: Agostino Nifo revisore dei 'De animalibus' gaziani. Medioevo. Rivista di storia della filosofia medievale 22. 259-301.

Perfetti, S. 2000: Aristotle's zoology and its Renaissance commentators, 1521-1601. Leuven.

Perotti, N. 1489: Cornu copiae. Venice (GW M31093).

Pliny 1857: Bostock, J., Riley, H. T. (transl.). The Natural history of Pliny. Vol. 6. London.

Pliny 1897: von Jan, L., Mayhoff, K. (eds.). C. Plinius Secundus. Naturalis historia. Vol. 4. Leipzig.

Ray, J. 1713: Synopsis methodica avium et piscium. London.

Riedl-Dorn, C. 1989: Wissenschaft und Fabelwesen. Ein kritischer Versuch über Conrad Gessner und Ulisse Aldrovandi. Wien; Köln.

Springer, K. B., Kinzelbach, R. K. 2009: Das Vogelbuch von Conrad Gessner (1516-1565). Ein Archiv für avifaunistische Daten. Berlin; Heidelberg.

Stresemann, E. 1975. Ornithology. From Aristotle to the present. Cambridge [Mass.]-London.

Sundevall, C. J. 1863: Die Thierarten des Aristoteles von den Klassen der Säugethiere, Vögel, Reptilien und Insekten. Übersetzung aus dem Schwedischen. Stockholm.

Thompson, D. W. ${ }^{1} 1895,{ }^{2} 1936$ : A glossary of Greek birds. Oxford.

Turner, W. 1544: Avium praecipuarum, quarum apud Plinium et Aristotelem mentio est, brevis et succincta historia. Cologne.

Turner, W. 1903: Evans, H. A. (ed., introd., transl.). Turner on birds. A short and succinct history of the principal birds noticed by Pliny and Aristotle, first published by Doctor William Turner. Cambridge.

Vorobyev, G. 2015: [Theodore Gaza's neologisms in his translation of Aristotle's De animalibus and their reception in modern zoology]. Indoevropeyskoe yazykoznanie $i$ klassicheskaya filologiya [IndoEuropean linguistics and classical philology] 19. 158-168. Воробьев Г. М. 2015: Неологизмы Феодора Газы из его латинского перевода «De animalibus» Аристотеля в современной зоологической номенклатуре. Индоевропейское языкознание $u$ классическая филология 19. 158-168. 
Vorobyev, G. 2018: Sylvia: Zur Entstehung des wissenschaftlichen Namens der Grasmücke (Arist. Hist. an. 592b22). Philologia Classica 13(2). 247-264.

Vorobyev, G. 2019: Einige Sperlingsvögel und eine Schlange. Noch einmal $\mathrm{zu}$ Arist. Hist. an. 592b22. Indoevropeyskoe yazykoznanie $i$ klassicheskaya filologiya [Indo-European linguistics and classical philology] 23. 178-191.

Walde, A. 1938-1954: Lateinisches etymologisches Wörterbuch. 3. neubearbeitete Auflage von J. B. Hofmann. Vols. 1-2. Heidelberg.

Willoughby, F. 1676: Ornithologiae libri tres. London. 